\title{
BANKING REFORM. SURVEILLANCE OF PRUDENTIAL BANKING FINANCIAL ACTIVITIES
}

\author{
Carmen Adriana GHEORGHE
}

\begin{abstract}
The rules of prudential supervision have brought more success to the efficiency of banking, which is protected from practices that could be harmful. The regulations contained in the rules applicable to the systemic ensemble are recognized in the supervision through the legal relationship between the supervisory authority and the credit institution. Through the legally established principles, the National Bank of Romania develops the potential requirements imposed on credit institutions and establishes a regular reporting in the conduct of supervisory activity. All credit institutions have an obligation to draw up their own regulations, rules to be complied with and operations to be carried out only after communicating them to the supervisory authority.
\end{abstract}

Key words: control, surveillance, prudence, banking system.

\section{Introduction}

In Romania, the main role of prudential supervision belongs to the National Bank of Romania, as an entity whose specific attribution is that of control activity over the complex and strong ensemble that is the financial-banking system.

The rules of prudential supervision have brought an extra success to the efficiency of the banking activity, this being protected from practices that could be harmful. The regulations contained in the rules applicable to the systemic ensemble are recognized in the supervision through the legal relationship between the supervisory authority and the credit institution.

The history of credit institutions has led to the practice of modern methods applied in their activity, and the events that give rise to legislative changes, constantly changing, have also changed the current European banking order. All these subtle adaptations take place against the background of the extraordinary flexibility of the legal norms and regulations of prudential supervision.

\footnotetext{
${ }^{1}$ Transilvania University of Braşov, Law Faculty, carmenghe@unitbv.ro.
} 
Through the legally established principles, the National Bank of Romania develops the potential requirements imposed on credit institutions and establishes a periodic reporting in the conduct of supervisory activity.

All credit institutions have the obligation to draw up their own regulations, rules to be complied with and operations to be carried out only after communicating them to the supervisory authority. The legal support for the obligation to comply with the norms imposed by the NBR on credit institutions is found in the provisions of art. 25 par. (2) of Law no. 312/2004 on the Statute of the NBR which refers to the measures taken by the NBR and their observance. In connection with these prudential requirements, credit institutions are required to have regulations and measures to report on the activity carried out, and in case of violations of legal provisions, sanctions are applied.

Also, the legislator provides that, if opened branches in EU Member States by Romanian legal entities, the central bank may carry out inspections at their premises and may cooperate with the supervisory authorities of the EU Member States.

Prudential risk control requirements aim to verify including capital adequacy, liquidity, minimum required reserves, level of assets, etc. Capital adequacy reflects the risks that the institution must assume and its ability to absorb losses. The European Central Bank ECB and the European System of Central Banks - ESCB have involved the NBR so that in its activity, the legal norms issued in the field are integrated in the European banking legislation. The legal provisions applied by the NBR are included in the Government Emergency Ordinance-O.U.G. no. 99/2006, as a source of principle.

Prudence, imposed by the legislation in force, protects from events that can bring unpleasant consequences, and supervision removes the effects that can lead to serious situations. Supervisory authorities have an important role to play at EU level, as this work is ongoing and involves special legal effects.

The lending requirements of public and private activities, activities for the development of which are frequently used for lending, thus manage to maintain the balance between the flow of money circulating on the European market and that circulating on the international market. At the same time, the activity of banks is monitored by reporting all indicators along with the development and expansion of banking policies in EU Member States and with legislative harmonization which also adds value to banking activities.

The aspects of harmonization of practices, of collaboration between banks and the business environment, of harmonization by implementing European banking legislation in the organization of its EU banks are supervised. Inter-banking legislative situations, of loans between banks and the private environment or between banks and banking groups are components of supervision. Banks, like every service user of credit institutions - natural or legal person, from the public or private sector - have strengths and weaknesses. They can offer less attractive products or services, and credit users can present risks for creditors and from here the prudential supervision activities acquire huge connotations in the control of the capital risk and of the other components of the bank funds.

Prudential supervision also aims at correct lending, without preferential methods. Prudence in lending principles and compliance with procedures are key 
because the absence of any conflict of interest must be verified when a credit institution approves lending and must also be assessed: quality of assets, adequacy of provisions and risk reserves for maintaining capital adequate against risks. Supervision also has the role of ensuring the credibility of the banking financial environment and not only, because the solvency of the entity is also investigated, as well as the causes that could lead to fraud. The central supervisor notifies the competent bodies for criminal actions, and in addition, analyzes the effects from the point of view of banking prudence in order to impose rules in the activity of other credit institutions.

Elements of prudential supervision are included in cross-border banking cooperation agreements. Cross-border cooperation and supervision is carried out through the crossborder banking cooperation and stability group and is represented by the relevant Financial Supervisory Authorities, relevant central banks and relevant finance ministries of countries with common financial stability concerns. Since the beginning of the banking activity, many positive elements of beneficial changes have been imposed in the structures of credit institutions and in the field of banking legislation, as a result of complex legal and legislative activities. These aimed at maintaining a strong legislative system, which would give the expected results in the functionality of the system, including all the elements of continuity.

\section{The framework of prudential supervision}

\section{1. The activity of the National Bank of Romania in the field of European prudential supervision}

Agreement concluded between the Banking Commission- $\mathrm{COB}$, based on the Basel Principles for Effective Banking Supervision (Basel Committee on Supervisory Issues) and the National Bank of Romania on cooperation and exchange of information for the purpose of conducting banking and prudential supervision determines the maintenance of the highest standards of prudential. The Basel Committee on Banking Supervision has issued Basic Principles 23, 24 and 25 for effective banking supervision on the supervision of entities operating across borders. It aims to maintain confidence in national and international financial systems and reduce the risk of loss for depositors.

Regarding the Cooperation Agreement between the NBR and the Deposit Guarantee Fund in the Banking System (FGDB) it is a measure of stability and guarantee of depositors and protection of their funds.

On a larger scale, the Cooperation Agreement between financial supervisors, central banks and EU finance ministries on cross-border financial stability helps to resolve cross-border systemic crises in which the parties strive to find common solutions to situations with potential negative effects.

Within particular character Multilateral Agreement on practical arrangements for the exchange of information in accordance with Article 57 (2) of Directive (EC) 2015/849, concluded between the ECB and the competent national authorities supervising the risks of money laundering and terrorist financing to which credit 
institutions and financial institutions are exposed produces their effects between signatories only in respect of financial-banking terrorism.

2020 began with specific social and health aspects - COVID pandemic 19, so that the meeting of the General Council of the National Committee for Macro prudential Supervision-CNSM, established in accordance with Law no. 12/2017, debates took place in which analyzed elements aimed at macro prudential policy and systemic risk. The capitalization of systemic risk must not lead to disproportionate negative effects on parts or all of the financial system at the level of other Member States or the European Union and must not lead to the formation or creation of an obstacle to the functioning of the internal market (Regulation No. 2/2017 on the methodology and procedure used to establish the shock absorber for systemic risk (Article 26, paragraph (6), (c)).

Some important elements were those regarding the possible impact on the financial system generated by the normative acts that suspend the payment of credit installments and the analysis related to the capacity of the banking sector to manage unfavorable developments. Macro prudential policy measures were approved, including CNSM Recommendation no. $\mathrm{R} / 1 / 2020$, and in the current context of the crisis, the additional capital requirement was considered inappropriate.

At the same time, taking into account that the total indebtedness continues to remain below the signal threshold, thus not being necessary to establish a level of countercyclical buffer rate higher than zero percent, it was estimated that the National Bank of Romania maintains the countercyclical capital buffer rate at 0 percent.

The crisis created in order to support banking financial institutions for the purposes of operational activities is postponed by one year implementation plan to IFRS (International Financial Reporting Standards) which are a set of accounting standards and are issued by the International Accounting Standards Board).

The National Committee for Macro prudential Supervision was established based on Law no. 12/2017 on the macro prudential supervision of the national financial system, thus ensuring the implementation of the Recommendation of the European Systemic Risk Board (ESRB) no. 3/2011 on the macro prudential mandate of national authorities. The CNSM includes representatives of the National Bank of Romania, the Financial Supervisory Authority and the Government. The mission of CNSM is to ensure the coordination in the field of macro prudential supervision of the national financial system, through appropriate instruments.

The role of prudential supervision plays an important and decisive role in the cooperation between the Financial Supervisory Authorities, the central banks and the Ministries of Finance, which must cooperate with the partner authorities of the other countries.

Also, in addition to the agreements to which it is a party, Romania has been concerned to adopt - through national measures - the essential international regulations in the field. By transposing into internal norms - O.U.G. no. $37 / 2019$ for the amendment and completion of the Government Emergency Ordinance- O.U.G.no. 202/2008 on the implementation of international sanctions, Law no. 129/2019 for preventing and combating money laundering and terrorist financing, as well as for amending and 
supplementing some normative acts, Regulation no. 2/2019 on preventing and combating money laundering and terrorist financing, Council Implementing Regulation (EU) 2020/8 of 7 January 2020 on the implementation of Article 12 (1) of Regulation (EU) 2017 / 1770- European policy in the field of risk reduction and systemic is pursued and applied.

\subsection{Lending practices and prudence}

The specificity of the banking activity also requires prudential techniques for risk control. In by the methods of making lending practices and lending commoner monetary control, whereby see implication credit policies and competitive interest rates so that every credit method include a controlled risk. Prudential supervision obliges banking institutions to control risk and keep risk to a minimum. For example, in the field of lending to commercial banks, we find the limitation on financing short-term assets, the use of safe and productive assets, so that the lending method involves minimal risk. As young commercial banks are restrictive in terms of asset quality, they would have no additional restrictions on interest rates to limit risk-taking.

The working capital market worldwide is functional and spontaneous and we notice that the large capital markets are correlated and the operators form a complex set of networks and products, pursued and controlled in Europe by states through European banking legislation. The global market is increasingly dictating to national markets and the ease of communication develops trade, so that financial transactions grow more and more, and Europeans expand and diversify by proposing new forms of credit and borrowing, all of which are pursued by banking regulation.

To assume the risks of bank lending, procedures and methods of granting loans have high real interest rates, but also a low level of interest, because for losses on nonrepayment of loans, to minimize the threat of bankruptcy, coordinating and supervisory authorities prudential can force banks to opt for a lower level of interest rates. Banking regulations from the point of view of risk, provide for a capital that is directly proportional to the credit risk. Protection against systemic risk is obtained through prudential regulations applicable to credit institutions. Prudential supervision aims to reduce the risks assumed by credit institutions. Also, the prudential supervisory authorities - NBR in the country and European Authority in the EU monitor these institutions to ensure that they comply with the rules of banking prudence and do not have excessive risk exposures. In case of non-compliance with the regulations, sanctioning measures are taken where appropriate, from recommendations to the effective application of sanctions.

This means - which focuses on the solvency, liquidity and profitability of each bank aims at the financial stability of credit institutions. Also, prudential supervision is a means of protecting the interests of creditors by verifying the granting of loans correctly, without preferences, and maintaining the stability of the entire banking system. Prudential supervision indirectly provides protection to consumers, because by maintaining the solvency of banks, losses generated by bank failures can be avoided. 


\subsection{Authorized supervision of credit institutions}

The legal framework for carrying out banking activity is given by the Government Emergency Ordinance O.U.G.- no. 99/2006, and it imposes the legal conditions under which a credit institution has access to the system of lending activities. Art.18 of the Ordinance regulates asset classes that may carry credit institutions, of which at point b), is included granting Growth - consumer loans, mortgages, factoring with or without recourse, financing of commercial transactions, including lump sums.

Prudential supervision, through the supervisory authority, allows the credit institution to effectively carry out its activity on the territory of the country, but to be able to set up subsidiaries or branches abroad as well. Branches and / or subsidiaries may be opened outside the country in accordance with the law.

We must mention that art.18 has undergone important subsequent amendments by O.U.G. no. 26/2010 and by O.U.G. no. 113/2013.

An authorization of the NBR is mandatory, because it is empowered to establish the conditions under which the authorization is granted and also to prepare the documentation, according to the conditions established by its own regulations. The European Banking Authority is notified, imperatively, according to European regulations. The National Bank of Romania regulates by Regulation no. 11/2007 the aspects of elaboration of the documentation regarding the authorization of the credit institutions, Romanian legal entities, and of the Romanian branches of the credit institutions from third countries, with the subsequent modifications and completions.

Art. 18, introduced by Law no. 312/2015 of December 14, 2015, regulates the activity of the credit institution regarding the guarantee of the deposited amounts. A further requirement is required disposition of funds equal to the minimum initial capital determined to conduct banking activities. Also, the capital, which through the old regulation, could be paid within two years, once the 2006 regulation enters into force, must be deposited, respectively paid in full at subscription, without contributions in kind. The payment of the cash brought as a contribution is made in an account opened at a credit institution and remains blocked until the registration of the Romanian legal entity in the Trade Register.

Article 106 and following of O.U.G. no. 99/2006 provide for the fulfillment of the legal requirements for the persons who have entrusted responsibilities - directors, administrator. When we refer to the registered office, it should be mentioned that this is the place where the company establishes its administrative domicile and its correspondence is communicated to it.

The real headquarters is, according to art. 14 of O.U.G. no. 99/2006, the place where the management center is located and the management activity is carried out, if it is not carried out at the registered office.

Returning to art.18, the legislator demonstrates his concern for the amounts deposited with a credit institution. The exceptions are contained in art. 19, which refers to the granting of mortgage loans that are financed by mortgage bond issues. They may take place under the conditions of the relevant legislation. These provisions complement those of art. 18 paragraph (4) which stipulates that activities that, 
according to special laws, are subject to specific approvals or approvals, cannot be activities that are not carried out within the legal framework of the O.U.G. no.99 / 2006.

The supervisory authority shall monitor compliance with the legislative provisions of these institutions and enforce them accordingly.

\subsection{The topicality of the European legislation in the matter and the internal modifications}

In order to maintain the best possible compliance and precise compliance with the conditions imposed by European regulations, national legislation has frequently been amended and supplemented, both in terms of prudential supervision and adaptation rules of lending principles.

The purpose is to obtain an optimal result of the activity of credit institutions, but also of the protection of credit consumers, through prudential supervision using sanctions in case of non-compliance.

\section{The role of ASF}

In Law no. 29/2015 for the approval of O.U.G. 113/2013 on some budgetary measures and for the amendment and completion of O.U.G. no. 99/2006 on credit institutions and capital adequacy, in article VIII point 4 article $4^{\wedge} 1$, after paragraph (2) a new paragraph shall be inserted stating that "The Financial Supervisory Authority collects and processes any relevant data and information, including the nature of personal data, necessary to assess the compliance of financial investment services companies, as well as, where appropriate, authority responsible for the supervision on a consolidated basis of financial holding companies and mixed financial holding companies, in accordance with the prudential requirements of this Emergency Ordinance, Regulation (EU) No $182 / 2011,575 / 2013$ and the regulations issued in their application, and for the investigation of possible violations of these requirements. " These rules are mandatory for the protection of personal data.

\section{Prohibition of cumulating of functions}

In Article VIII, a new point shall be inserted after point 65 , point $65 \wedge 1$, with the following content. "In the case of a credit institution managed in a unitary system, the chairman of the board of directors must not simultaneously exercise the position of general manager within the same credit institution.

Good reputation and prudent and healthy banking practice

At the same time, Article VIII, point 67 (1) of Article 108 states that each member of the Management Board and its Directors, as appropriate, the members of the Supervisory Board and the Management Board of a credit institution, as well as the persons designated to manage structures relating to the activities of risk management and control, internal audit, legal, compliance, treasury, lending, as well as any other activities which may expose the credit institution to significant risks must at all times have a good reputation, knowledge, skills and experience appropriate to the nature, scope and complexity of the activity of the credit institution and the responsibilities 
entrusted to it and must carry out its activity in accordance with the rules of prudent and sound banking practice. "

\section{Concluding contracts in a prudent manner. Consumer law}

Art. Art.117 ^ 2 states that "credit institutions may conduct transactions with customers only on a contractual basis, acting in a prudent manner and in compliance with specific legislation in the field of consumer protection."

\section{Prohibition of conditioning}

After Article 119, a new Article, Article $119 \wedge 1$, is inserted with the following content. "Credit institutions may not make the granting of loans or the provision of other products and services to customers conditional on the sale or purchase of shares, securities or financial instruments issued by the credit institution or another entity belonging to the group to which the credit institution belongs or the acceptance by the customer of other products or services offered by the credit institution or an entity belonging to its group, which are not related to the lending operation or to the requested product or service.

\section{The issuer of the sanctioning act}

In Article VIII, point 176 (2) of Article 233, the amendment provides that "acts relating to a credit institution by which measures are imposed or sanctions and sanctions are applied in accordance with this Chapter shall be issued by the Governor, the first vicegovernor or vice-governors of the National Bank of Romania, except for the establishment of the special supervision, of the withdrawal of the approval granted to the persons provided in art. 108 par. (1), the withdrawal of the authorization of the credit institution and the suspension of the exercise of the voting right of the shareholders or members of the credit institution, the application of which is within the competence of the board of directors. "

\section{Offenses. Lack of authorization}

Article 410 is amended so that the legislator tells us that the conduct, without right, of activities among those provided in art. 5 par. (1), as well as the beginning of the activities as a credit institution, without obtaining the authorization according to the provisions of art. 10 par. (1), constitutes a crime and is punishable by imprisonment from one year to 5 years.

\section{Re- knowledge of court decisions and lending}

As an operating principle, the legal form of constitution of credit institutions, as the only form, is a joint stock company. The mentioned legal form is in accordance with all the special provisions of O.U.G. no. 99/2006. The companies are constituted according to art. 2 of the company law no.31/1990, so the partnership contract of credit institutions must fulfill the form of joint stock company. Law no. 85/2014 on insolvency 
prevention procedures provides, at art. 344 , that on the date of its entry into force, O.G. no. $10 / 2004$ is repealed.

This fact determined that the procedure applicable to professionals, defined in art. 3 paragraph 2 of the Civil Code, to be the one contained in Law no. 85/2014. Thus, art. 38182 in the matter of insolvency procedure is applied, according to art.204, in accordance with the bankruptcy procedure of credit institutions.

Bankruptcy judge receives extra duties (art. 207)- appeal, the debtor credit institution against the petition filed by NBR, judging the requests for attracting the liability of the members of the management bodies and the appeals formulated by the representative of the shareholders of the debited credit institution. Recognize court judgments cause the system to operate in a more efficient and expeditious manner.

Harmonized European legislation is an important step that leads to major security in all areas and, above all, we could say, in the economic context, because it is known that most of the disputes present are of a commercial nature.

Both citizens and companies find themselves in a functional system that guarantees a major security in the development of economic activities and, implicitly, of credit applications, for the development of companies, which are no longer afraid of nonrecognition of judgments in the European Union.

In the European Union, in civil and commercial proceedings, competence is given by Regulation no. 44/2001 (Brussels I Regulation) governing the recognition and enforcement of judgments in civil and commercial matters in the European Union.

With regard to the Member States of the European Union, the issue of recognition of foreign judgments has been initiated since the Brussels Convention on the Recognition of Foreign Trade Judgments, 1968.

Concrete aspects regarding supervision. Italy

Internationally, Italy is among the states that have refrained from concluding treaties. Thus, treaties have been signed with a small number of countries, such as Switzerland, Norway, Argentina, Brazil, Egypt and Turkey. For this reason, in most countries of the world, the judgments of Italian judges are not recognized. All signatory countries ensure compliance with these judgments, the only limits being the observance of the right of defense of the parties and the existence of other judgments, previously issued, pronounced on the same controversy. In view of the above, in order to avoid uncertainty and the risk of referring a judge other than the one desired, it is certainly necessary to include in the contractual text or in the Contract Conditions, a competent jurisdiction. EU Regulation no. 1215/2012, starting with 2015, replaced the EC Regulation no. 44/2001. EU Regulation No. 2015/2012 is applicable from January 2015 instead of EC Regulation 44/2001, being the last of the many actions of the legislation adopted within the European framework and has as main objective the final elimination of obstacles to the recognition and enforcement of judgments in the Member States of Union.

Regarding the criteria for determining jurisdiction, the new EU Regulation No $1215 / 2012$ does not present any apparent revision of EC Regulation 44/2001.

On the one hand, there remains, on the one hand, the rule that the courts of the Member State in which the defendant is domiciled or the place where a corporation is 
established have jurisdiction and, on the other hand, the alternative possibility litigation 'before the court that the obligation in question is to be performed". The main innovation introduced by EU Regulation 1215/2012 (Art. 2.1, subsection (a), old art. 5.1 of EC Regulation No 44/2001) is the elimination of the necessary procedures for the decision of the court, pronounced by a court of a Member State, become enforceable in another Member State. The old rules of the EC - for instance, Regulation no. 44 / 2001provided that a judgment given in one Member State, which was enforceable, could be enforced in another Member State after it had been recognized by the competent authorities at the request of the party concerned.

Given that credit can be granted in all European countries, European citizens can conclude credit agreements anywhere. This creates the risk of non-repayment of the loan. The recognition of judgments and the titles of their execution, banks can easily recover debts from borrowers.

The new regulation seeks to simplify the procedure, stating that "a judgment given in a Member State which is enforceable in one Member State is also enforceable in other Member States" (Judicial cooperation in civil matters in the European Union, https : //ejustice.europa.eu. ).

\section{Conclusions}

The particularities of the banking systems, the types of financial-banking institutions, the banking competition, the specifics of the organization and development of the banking activity, as well as the aspects of the banking history and culture influence the activity of the credit institutions. The operations and the role of banks in the economy and the typology of risks to which they are exposed differentiate the contemporary banking activity. The organization and types of banking operations, the characteristics of products and services represent an important factor of the banking supervision activity.

The decision-making process, influenced by the information system, contributes to the perspective of developing the complex circuit of credit institutions' activities. The positive evolution, the continuity of the activity and the trust offered to the clients in the banking system, show the correct development of the activities and the management, the credit institutions respecting the principles of prudence.

Also, banking is influenced by the online environment, as it is faster and more and more online lending methods and techniques have been developed that can become the method of the future, as it approaches fast lending methods and simulations, through innovative software, which does not require waste of time from consumers and at the same time allows numerous comparisons of interest rates, periods, guaranteed amounts, more convenient terms and conditions.

Throughout history, the institutions of credit have developed and acted independently, with its own funds (the activity of some failing in bankruptcy and disappeared). Other banks have transformed by merging, but in times of crisis we see that, although some of them benefited from intense activities developed through traders' trade, their situation was often identical to that mentioned above. 
Even today, considering only the last ten years, we can see that some activities of credit institutions have led to unfavorable situations, which is undesirable in the activities of banking institutions, both for consumers and depositors, and for affecting the image, trust in the credit institution system.

In terms of doctrinal matters banking on conditions create the EU single system of organization, control and surveillance - opinions are devided-some authors pointing out that the system is not suitable for all. Most recognize the benefits of the system, because only through legislative control and prudential supervision, with the help of the national central banks of each Member State and the European Central Bank, can the system of credit institutions operate in appropriate conditions, appropriate to the current situation.

The activities of banks with public, private and mixed capital have determined the increase of the development level of the banking system, but also the increase of the companies' activity, a dimension represented by the size of the assets.

The activities of credit institutions are also considerably influenced by the number of banking operations, the number of bank employees and the number of secondary offices. All aspects of the banking activity influence the development of acquisitions and mergers, as this widens the product ranges and services. As in other European states, in Romania, along with commercial banks, the Romanian system includes a network of credit cooperatives - Creditcoop, banks specializing in saving and lending activities, as well as non-banking financial institutions, which operate a wide range of operations, consumer lending, real estate lending and microcredit. They are subject to prudential supervision.

Control and supervision prudent to be conducted in accordance with banking principles and along the basic rules is European, and bank supervisors and supervisory colleges have the responsibility and the direct implication on bank operations as well as responsibility for the decisions people playing a leading role in banks (managers and administrator).

Thus, the role of prudential banking supervision is to obtain assurance that bank managers comply with legal regulations, thus protecting banking institutions from unfavorable situations, which may be due to the risks assumed as a result of transactions. Banking institutions have control systems that require guarantees. The regulation from art. 120 / O.U.G no.99 / 2006 provides in the sense that the real guarantee contracts concluded with credit institutions represent executory titles, so it constitutes a precautionary measure, a measure that gives credit institutions the possibility to recover the amounts granted.

Are encouraged banking prudence in order not to be reached in difficulty, and if the entity is experiencing imbalances financial, they are controlled, analyzed and managed so as to minimize systemic risk and impaired ability of these institutions to carry out it s activity.

\section{References}

Aldcroft, D.H. (1997). The European economy from 1914 to 1990. Rome: Laterza. 
Anghelache, G. (1997). Capital markets and stock exchange transactions. Bucharest: Didactica RA.

Bank of Italy (2016). Consumer credit in simple words. Rome: Editura Divisione Editoria della Banca d'Italia.

Bertinetti, G., Farinet, A., Nova, A., Zanderighi, L. (1998). Sistemaltalia. Milan: Estaslibri. Căpraru, B. (2013). Banking, Operations and Practical Systems. Bucharest: C.H. Beck.

Căpraru, B. (2009). Retail Banking. Bucharest: C.H.Beck.

Chini, A. (2003). Stock market: how to choose and winning shares. Milan: II Sole 24 Ore.

Deacon, N. (2017). European Union Law, EU Policies. Bucharest: The Legal Universe.

Dobrilă, M.C. (2019). European contract law. Bucharest: A legal universe.

Dobrilă, M.C. (2019). European Business Law, Principles, Policies, Single Market. Bucharest: The Legal Universe.

Gheorghe, C.A. (2014). Banking law. Bucharest: C.H.Beck.

Gheorghe, C.A.(2018). Community banking law. Bucharest: C.H.Beck.

Practical guide for the application of regulations in accordance with European directives

(2013). Bucharest: CECCAR.

Expert's Guide (2013). Bucharest: CECCAR.

Regulations compliant with European directives (2013). Bucharest: CECCAR.

***www.bancaditalia.it/compiti/vigilanza/intermediari/TUB_febbraio_2016.pdf

***www.cursdeguvernare.ro/riscurile-anului2017-si-finantatorii-lor

***www.lege5.ro/gratuit/geydcobrhe/orodonanta-de-urgenta-nr-99-2006

$* * *$ www.europarl.europa.eu/atyourservice/ro/

$* * *$ www.ec.europa.eu/consumers

***www.ec.europa.eu/civiljustice

$* * *$ www.eur-lex.europa.eu/legal-content

***www. biblioteca.regielive.ro/proiecte/banci/sistemul-bancar-din-Olanda

$* * *$ www.cnsmro.ro/comunicate-de-presa/

***www.bnr.ro/Acorduri-in-domeniul-supravegherii

$* * *$ www.pariopportunita.gov.it/

$* * *$ www.ingenere.it

$* * *$ www. repec.kse.org.ua

$* * *$ www.researchgate.net/publication

$* * *$ www. banknews.ro

$* * *$ www.bancaditalia.it/sispaga/sms/sepa

$* * *$ www.rasfoiesc.com-banks / lending activity

***www.spremutedigitali.com/donna-2017-finanziamenti

$* * *$ www.banca-del-mezzogiorno / medioCreditoCentrale

$* * *$ www.bnr.ro/apage-mobile.aspx

***www.cnsmro.ro/sedinta-cnsm-din-8-mai-2020/ 